\title{
Pharmacological characterization of the relaxant effect induced by adrenomedullin in rat cavernosal smooth muscle
}

\author{
L.N. Leite ${ }^{1,3}$, N.A. Gonzaga ${ }^{1}$, D.P.C. Tirapelli ${ }^{2}$, L.F. Tirapelli ${ }^{2}$ and C.R. Tirapelli ${ }^{3}$ \\ ${ }^{1}$ Programa de Pós-Graduação em Farmacologia, Faculdade de Medicina de Ribeirão Preto, \\ Universidade de São Paulo, Ribeirão Preto, SP, Brasil \\ ${ }^{2}$ Departamento de Cirurgia e Anatomia, Faculdade de Medicina de Ribeirão Preto, \\ Universidade de São Paulo, Ribeirão Preto, SP, Brasil \\ ${ }^{3}$ Laboratório de Farmacologia, Departamento de Enfermagem Psiquiátrica e Ciências Humanas, \\ Escola de Enfermagem de Ribeirão Preto, Universidade de São Paulo, Ribeirão Preto, SP, Brasil
}

\begin{abstract}
The aim of the present study was to determine the mechanisms underlying the relaxant effect of adrenomedullin (AM) in rat cavernosal smooth muscle (CSM) and the expression of AM system components in this tissue. Functional assays using standard muscle bath procedures were performed in CSM isolated from male Wistar rats. Protein and mRNA levels of pre-proAM, calcitonin receptor-like receptor (CRLR), and Subtypes 1, 2 and 3 of the receptor activity-modifying protein (RAMP) family were assessed by Western immunoblotting and quantitative real-time polymerase chain reaction, respectively. Nitrate and 6keto-prostaglandin $\mathrm{F}_{1 \alpha}$ (6-keto-PGF $1 \alpha$; a stable product of prostacyclin) levels were determined using commercially available kits. Protein and mRNA of AM, CRLR, and RAMP 1, -2 , and -3 were detected in rat CSM. Immunohistochemical assays demonstrated that AM and CRLR were expressed in rat CSM. AM relaxed CSM strips in a concentration-dependent manner. $\mathrm{AM}_{22-52}$, a selective antagonist for $\mathrm{AM}$ receptors, reduced the relaxation induced by $\mathrm{AM}$. Conversely, $\mathrm{CGRP}_{8-37}$, a selective antagonist for calcitonin gene-related peptide receptors, did not affect AM-induced relaxation. Preincubation of CSM strips with $\mathrm{N}^{\mathrm{G}}$-nitro-L-arginine-methyl-ester (L-NAME, nitric oxide synthase inhibitor), 1H-(1,2,4)oxadiazolo[4,3-a]quinoxalin-1-one (ODQ, quanylyl cyclase inhibitor), Rp-8-Br-PET-cGMPS (cGMP-dependent protein kinase inhibitor), SC560 [5-(4-chlorophenyl)-1-(4methoxyphenyl)-3-trifluoromethyl pyrazole, selective cyclooxygenase-1 inhibitor], and 4-aminopyridine (voltage-dependent $\mathrm{K}^{+}$ channel blocker) reduced AM-induced relaxation. On the other hand, 7-nitroindazole (selective neuronal nitric oxide synthase inhibitor), wortmannin (phosphatidylinositol 3-kinase inhibitor), H89 (protein kinase A inhibitor), SQ22536 [9-(tetrahydro-2furanyl)-9H-purin-6-amine, adenylate cyclase inhibitor], glibenclamide (selective blocker of ATP-sensitive $\mathrm{K}^{+}$channels), and apamin $\left(\mathrm{Ca}^{2+}\right.$-activated channel blocker) did not affect AM-induced relaxation. AM increased nitrate levels and 6-keto-PGF $1 \alpha$ in rat CSM. The major new contribution of this research is that it demonstrated expression of AM and its receptor in rat CSM. Moreover, we provided evidence that AM-induced relaxation in this tissue is mediated by AM receptors by a mechanism that involves the nitric oxide-cGMP pathway, a vasodilator prostanoid, and the opening of voltage-dependent $\mathrm{K}^{+}$channels.
\end{abstract}

Key words: Rat cavernosal smooth muscle; Adrenomedullin; Relaxation; Nitric oxide; Calcitonin receptor-like receptor

\section{Introduction}

The initiation and maintenance of penile erection is caused by relaxation of the blood vessels in the cavernosal smooth muscle (CSM), which results in an increased blood flow into the trabecular spaces of the corpora cavernosa (1). The control of CSM tone is mainly mediated by the adrenergic, cholinergic, and nonadrenergic, noncholinergic (NANC) systems (2). Noradrenaline, released from sympathetic nerves, induces contraction of penile CSM while parasympathetic innervations mediate smooth muscle relaxation in the trabecular network and cavernosal arterial venous bed (3). Nitric oxide (NO) released from NANC nerve endings and from the vascular endothelium is considered the most important mediator of CSM relaxation (4). Release of endothelium-derived $\mathrm{NO}$ is regulated by several factors, including vasodilator substances such as adrenomedullin (AM), which has

Correspondence: C.R. Tirapelli, Laboratório de Farmacologia, Departamento de Enfermagem Psiquiátrica e Ciências Humanas, Escola de Enfermagem de Ribeirão Preto, USP, Av. Bandeirantes, 3900, 14040-902 Ribeirão Preto, SP, Brasil. Fax: +55-16-36333271. E-mail: crtirapelli@eerp.usp.br 
been demonstrated to play a role as a modulator of erectile function (5-7).

AM consists of a 52-amino acid peptide, initially isolated from human pheochromocytoma cells, that displays vasorelaxant and hypotensive actions (8). AM has a ring structure formed by a disulfide bond and an amidated carboxyl terminal, and belongs to a family of peptides that include amylin and calcitonin gene-related peptide (CGRP) (8). In the vasculature, the relaxant response induced by $\mathrm{AM}$ is mediated by the seven-transmembrane $G$ protein-coupled calcitonin receptor-like receptor (CRLR), which coassembles with Subtypes 2 and 3 of the receptor activity-modifying protein (RAMP) family, thus forming a receptor-coreceptor system $(9,10)$. Although the vasodilator effect of AM in different blood vessels is well characterized (10), few reports have described the effect of AM in CSM relaxation. However, it has been reported that intracavernosal injections of AM increased cavernosal pressure and penile length in cats (5). This response was not mediated by CGRP receptors and did not involve $\mathrm{NO}$ generation or the opening of $\mathrm{K}^{+}$ channels $(5,6)$. In anesthetized rats, intracavernosal administration of AM resulted in increased cavernous pressure and penile erection, which was attenuated by inhibitors of the NO-cGMP pathway (7). The relaxation induced by $\mathrm{AM}$ in isolated rabbit CSM strips does not involve $\mathrm{NO}$, vasodilator prostanoids, or the opening of $\mathrm{K}^{+}$ channels (11). Finally, AM is localized in human endothelial cells of cavernous vessels, where it may contribute to penile erection (12). These findings imply that $A M$ is a modulator of CSM tone and suggest that AM might potentiate erectile function. Moreover, based on the above-mentioned observations, it is possible to conclude that the mechanism by which AM induces vasorelaxation or erection varies with species, vascular bed studied, and experimental procedure employed.

The AM system has been postulated to have a cardioprotective role in a wide range of diseases (13). Cardiovascular diseases are often associated with erectile dysfunction (ED) (14), and, in this case, increased levels of AM may play a compensatory role for ED. Isolated CSM is a useful model for the study of penile erectile responses and ED $(15,16)$. Thus, the study of physiological expression and function of AM receptors in CSM may provide valuable information on the contribution of AM to CSM tone. The effect of AM on cavernous pressure and penile erection has been previously evaluated in anesthetized rats using intracavernous pressure measurements (7). However, to the best of our knowledge, there are no reports describing the receptors involved in AM-induced relaxation of rat CSM or the detailed mechanisms underlying such a response. The aims of the present study were to attempt a functional characterization of the AM receptors in rat CSM and to investigate the mechanisms underlying $A M$-induced relaxation in this tissue. In addition, quantitative real-time polymerase chain reaction (qRT-PCR), Western immunoblotting, and immunohistochemical assays were performed to verify expression of AM, CRLR, and RAMP1, -2 , and -3 in rat CSM.

\section{Material and Methods}

\section{Animals}

Male Wistar rats weighing 250-300 g (50-70 days of age) were housed under standard laboratory conditions with free access to food and water. The housing conditions and experimental protocols were approved by the Animal Ethics Committee of the Universidade de São Paulo, Campus of Ribeirão Preto, Brazil (Protocol $\#$ 10.1.1293.53.4). The animals were anesthetized with isoflurane [2-chloro-2-(difluoromethoxy)-1,1,1-trifluoroethane] and killed by aortic exsanguination. CSM was removed for functional assays, Western immunoblotting, qRT-PCR, and immunohistochemical experiments.

\section{qRT-PCR}

Total cellular RNA was extracted using Trizol ${ }^{\circledR}$ Reagent (Invitrogen, USA), and RNA was reverse transcribed to single-stranded cDNA using a High Capacity Kit (Applied Biosystems, USA) according to the manufacturer's protocol. For quantitative analysis of the genes of interest [pre-pro-AM (Rn 00562327 m1), CRLR (Rn 00562334_m1), RAMP1 (Rn 01427056_m1), RAMP2 (Rn 00824652_m1), and RAMP3 (Rn 00571815_m1)], a commercially available TaqMan Assay-on-Demand System that consists of a kit of oligonucleotides and probes was used (Applied Biosystems). Reverse transcription was performed using $1 \mu \mathrm{g}$ total RNA for each sample in $20 \mu \mathrm{L}$ of the total reaction mixture. The cDNA obtained was diluted $1: 10$, and $4.5 \mu \mathrm{L}$ was used for each $10 \mu \mathrm{L}$ of the qRT-PCR mixture using the TaqMan Master Mix (Applied Biosystems). Reactions were carried out in duplicate and analyzed with 7500 Sequence Detection System apparatus (Applied Biosystems). Data were analyzed using the ABI-7500 SDS software (Applied Biosystems). Total RNA absorbed was normalized on the basis of the $\mathrm{Ct}$ value for the GAPDH gene (Rn 01775763 m1). The variation in expression among samples was calculated by the $2^{-\Delta \Delta C t}$ method, and the mean delta $\mathrm{Ct}$ value for a group of six samples from the control was used for calibration (17).

\section{Western immunoblotting}

CSM was frozen in liquid nitrogen and homogenized in lysis buffer (50 mM Tris-HCl, pH 7.4, 1\% IGEPAL, 0.5\% sodium deoxycholate, $1 \%$ SDS). Homogenates were centrifuged at $5,000 \mathrm{~g}$ for $10 \mathrm{~min}$; the pellet was then discarded, and the supernatant was stored at $-80^{\circ} \mathrm{C}$. Sixty micrograms of protein were separated by electrophoresis on a $10 \%$ or $15 \%$ polyacrylamide gel and transferred onto a nitrocellulose membrane. The $15 \%$ 
polyacrylamide gel was used for AM separation. Nonspecific binding sites were blocked with $7 \%$ skim milk in Tris-buffered saline solution with Tween 20 for $1 \mathrm{~h}$ at $24^{\circ} \mathrm{C}$. The membranes were then incubated with the following specific antibodies (Santa Cruz Biotechnology, USA) overnight at $4^{\circ} \mathrm{C}$ : AM (sc-16496, 1:250 dilution), CRLR (sc-18007, 1:250), RAMP1 (sc-11379, 1:250), RAMP2 (sc-11380, 1:250), and RAMP3 (sc-11381, 1:250). Beta-actin (sc-1616, 1:2000) was used as an internal control. After the membranes were incubated with labeled secondary antibodies, signals were detected by chemiluminescence and visualized by autoradiography.

\section{Immunohistochemistry}

Paraffin-embedded CSM segments were stained using the avidin-biotinylated peroxidase complex method. Briefly, 4- $\mu \mathrm{m}$ sections (Reichert Jung 2040 microtome, Leica, USA) were cut, deparaffinized with xylene and dehydrated in ethanol. Endogenous peroxidase and biotin were blocked by immersing slides in 3\% hydrogen peroxide. The sections were incubated with the following primary antibodies: AM (sc-16496, 1:250) and CRLR (sc-18007, 1:250). The reactions were revealed using 0.2 $\mathrm{mg} / \mathrm{mL}$ diaminobenzidine solution (10 mg tablets in $50 \mathrm{~mL}$ PBS $0.01 \mathrm{M}, \mathrm{pH} 7.4$; D5905; Sigma-Aldrich, USA) and stained by Harris hematoxylin. On each slide, two fields were selected in areas with high concentrations of positive cells or stained cells, using $50 \times$ or $1000 \times$ magnification. The slides were analyzed using a Leica model DM 5500 B microscope. The images were registered using a Leica digital camera DFC 290 (3MP) attached to the microscope and filed using the Leica QWin software.

\section{Functional studies}

CSM was isolated as described previously (16). In brief, the penis was harvested by cutting the corporeal body at the level of its attachment to the ischium bone and then immersed in Krebs solution (130 $\mathrm{mM} \mathrm{NaCl}, 4.7 \mathrm{mM} \mathrm{KCl}$, $1.18 \mathrm{mM} \mathrm{KH} \mathrm{PO}_{4}, 1.17 \mathrm{mM} \mathrm{MgSO}{ }_{4} .7 \mathrm{H}_{2} \mathrm{O}, 1.6 \mathrm{mM}$ $\mathrm{CaCl}_{2} .2 \mathrm{H}_{2} \mathrm{O}, 14.9 \mathrm{mM} \mathrm{NaHCO}$, and $5.5 \mathrm{mM}$ glucose). The tunica albuginea was carefully opened from its proximal extremity toward the penile shaft, and the erectile tissue within the corpus cavernosum was surgically dissected free. Strips of CSM $(1 \times 1 \times 10 \mathrm{~mm})$ were mounted in a 5 $\mathrm{mL}$ organ chamber containing Krebs solution at $37^{\circ} \mathrm{C}$ and continuously bubbled with a gas mixture of $95 \%$ oxygen and $5 \%$ carbon dioxide, $\mathrm{pH} 7.4$. One end of each corporal strip was attached to the bottom of the organ bath and the other end was tied to a force transducer (TRI201, Panlab, Spain). The strips were stretched to a resting tension of $3 \mathrm{mN}$ and allowed to equilibrate for $60 \mathrm{~min}$. The responses were recorded on a computer system using Chart Pro 5 (PowerLab, ADInstruments, Australia).

CSM strips were precontracted with phenylephrine $(10 \mu \mathrm{M})$, and when the contraction reached a plateau, concentration-response curves for AM (10 fM to $30 \mathrm{nM}$ ) were obtained by stepwise increase of the agonist concentration. Additions were made as soon as a steady response was obtained from the preceding concentration. For comparison, concentration-response curves for CGRP (1 pM to $0.3 \mu \mathrm{M})$ and acetylcholine (1 $\mathrm{nM}$ to $1 \mathrm{mM}$ ) were also obtained in precontracted CSM strips. Relaxation is reported as the percent change from phenylephrine-contracted levels.

The mechanisms underlying AM-induced relaxation were evaluated by experiments performed in the presence of $100 \mu \mathrm{M} \mathrm{N} \mathrm{N}^{\mathrm{G}}$-nitro-L-arginine-methyl-ester [L-NAME, a nonselective NO synthase (NOS) inhibitor], $100 \mu \mathrm{M} 7$ nitroindazole [a selective neuronal NOS (nNOS) inhibitor], $1 \mu \mathrm{M} 1 \mathrm{H}-(1,2,4)$ oxadiazolo[4,3-a]quinoxalin-1-one (ODQ, selective guanylyl cyclase inhibitor), $3 \mu \mathrm{M}$ Rp-8-Br-PETcGMPS (cGMP-dependent protein kinase inhibitor), $10 \mu \mathrm{M}$ sildenafil (phosphodiesterase 5 inhibitor), $1 \mu \mathrm{M}$ wortmannin (phosphatidylinositol 3-kinase inhibitor), $10 \mu \mathrm{M}$ SC560 (selective cyclooxygenase-1 inhibitor), 1 mM 4-aminopyridine (selective blocker of voltage-dependent $\mathrm{K}^{+}$channels), $1 \mu \mathrm{M}$ apamin (selective blocker of low-conductance $\mathrm{Ca}^{2+}$-activated channels), $3 \mu \mathrm{M}$ glibenclamide (selective blocker of ATP-sensitive $\mathrm{K}^{+}$channels), $100 \mu \mathrm{M}$ SQ22536 (adenylate cyclase inhibitor), $1 \mu \mathrm{M} \mathrm{H} 89$ (cAMP-dependent protein kinase inhibitor), 0.01-1 $\mu \mathrm{M} \mathrm{AM}_{22-52}$ (AM receptor antagonist), or $0.1 \mu \mathrm{M} \mathrm{CGRP}_{8-37}$ (CGRP receptor antagonist). All drugs were incubated for $30 \mathrm{~min}$. Drug concentrations were selected from the literature (18-23). The agonist concentration-response curves were fitted using a nonlinear interactive fitting program (GraphPad Prism 3.0; GraphPad Software Inc., USA). Agonist potencies and maximal responses are reported as $\mathrm{pD}_{2}$ (negative logarithm of the molar concentration of agonist producing $50 \%$ of the maximal response) and $E_{\max }$ (maximum effect elicited by the agonist), respectively.

\section{Nitrate measurements}

Nitrate $\left(\mathrm{NO}_{3}^{-}\right.$, a metabolite of $\left.\mathrm{NO}\right)$ levels were measured in supernatants from CSM homogenates. The strips were contracted with $10 \mu \mathrm{M}$ phenylephrine and then exposed to $30 \mathrm{nM}$ AM or $100 \mu \mathrm{M}$ L-NAME. Some strips were incubated with $100 \mu \mathrm{M}$ L-NAME for $30 \mathrm{~min}$ prior to the administration of AM. When the maximal relaxation induced by AM was achieved, tissues were frozen in liquid nitrogen. CSM was homogenized in $200 \mu \mathrm{L}$ PBS buffer, $\mathrm{pH} 7.4$, and centrifuged at $10,000 \mathrm{~g}\left(10 \mathrm{~min}, 4^{\circ} \mathrm{C}\right)$. The supernatant was ultrafiltered (Amicon Ultra- $0.5 \mathrm{~mL}$ $10 \mathrm{kDa}$, Millipore, USA) at $14,000 \mathrm{~g}\left(15 \mathrm{~min}, 25^{\circ} \mathrm{C}\right)$. A commercially available kit (\#780001, Cayman, USA) was used to measure nitrate levels. Results are reported as $\mu \mathrm{M} /$ $\mathrm{mg}$ protein. Protein concentrations were determined with a protein assay reagent (Bio-Rad Laboratories, USA).

\section{6-keto-PGF ${ }_{1 \alpha}$ measurements}

6-keto-PGF ${ }_{1 \alpha}$, a stable hydrolyzed product of unstable prostacyclin $\left(\mathrm{PGI}_{2}\right)$, was measured in CSM homogenates. 

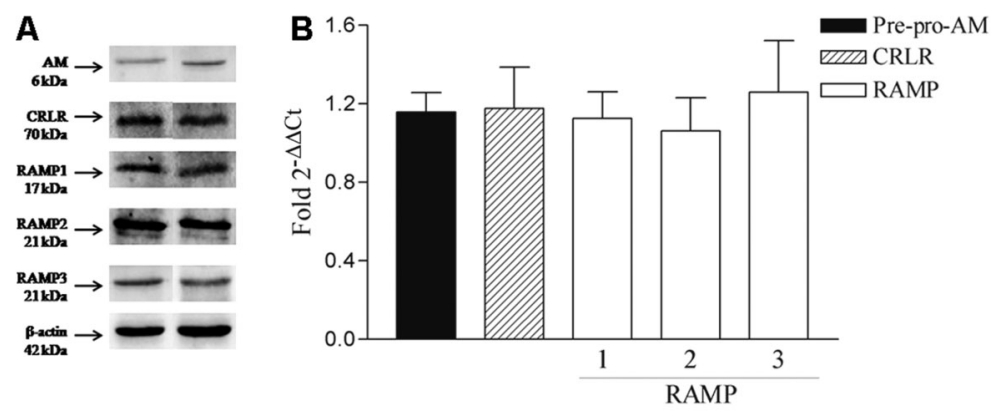

Figure 1. Protein and mRNA expression of AM system components in the rat CSM. A, Representative immunoblots for AM, CRLR and RAMP1, $-2,-3$ protein expression. $B$, mRNA expression of pre-pro-AM, CRLR and RAMP1, $-2,-3$ in the rat CSM was assessed by qRT-PCR. The results are reported as the expression of the individual mRNAs with normalization to the housekeeping gene GAPDH by using the Ct method. Data are reported as means \pm SE of $n=5$ to 7 CSM. AM: adrenomedullin; CSM: cavernosal smooth muscle; CRLR: calcitonin receptor-like receptor; RAMP: receptor activity-modifying protein.

The strips were contracted with $10 \mu \mathrm{M}$ phenylephrine and were then exposed to $30 \mathrm{nM}$ AM. When the maximal relaxation induced by AM was achieved, the strips were frozen in liquid nitrogen. CSM was homogenized in EIA

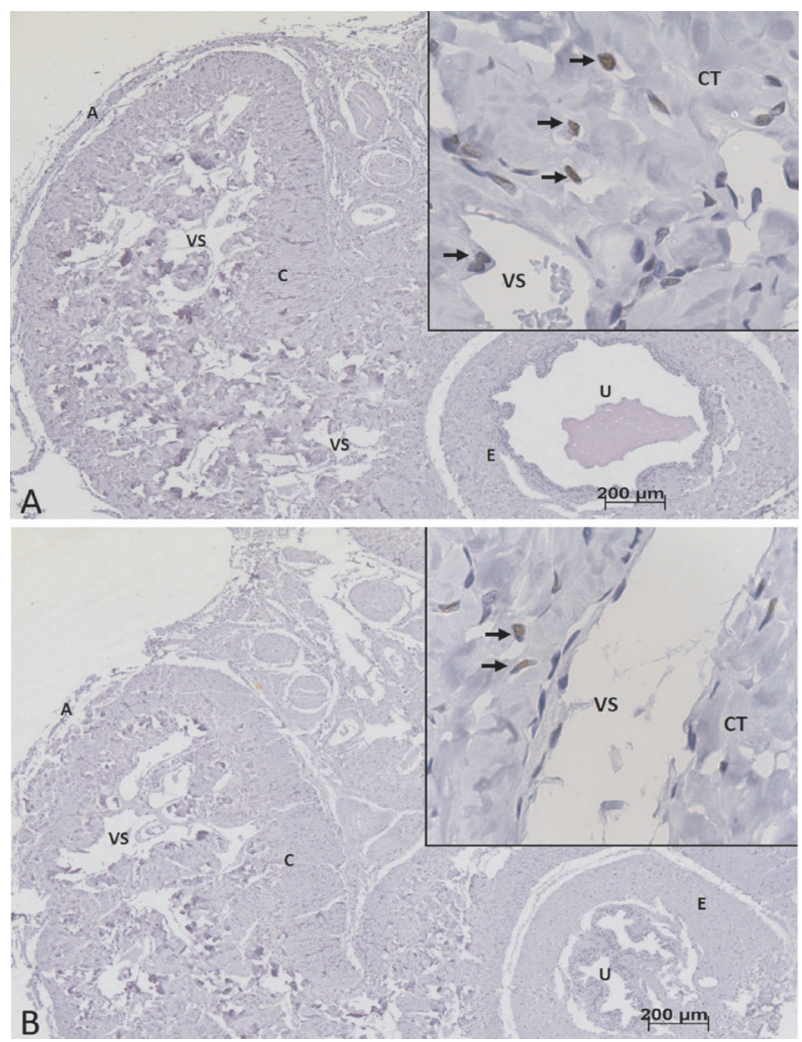

Figure 2. Representative immunohistochemical photomicrographs of adrenomedullin (AM) and calcitonin receptor-like receptor (CRLR) in rat cavernosal smooth muscle sections. AM $(A)$ and $\operatorname{CRLR}(B)$ nuclear staining (arrows on the images in detail) were detected diffusely in all constituents of the cavernous tissue (CT): connective tissue, endothelium lining the vascular spaces and in smooth muscle. A: tunica albuginea; C: corpora cavernosa; E: spongy body; VS: vascular spaces; U: urethra. Magnification $50 \times$ and $1000 \times$ (inset). buffer (1 M phosphate solution containing 1\% BSA, $4 \mathrm{M}$ sodium chloride, $10 \mathrm{mM}$ EDTA and $0.1 \%$ sodium azide) and centrifuged at $2000 \mathrm{~g}\left(15 \mathrm{~min}, 4^{\circ} \mathrm{C}\right)$. The samples $(50 \mu \mathrm{L})$ were deproteinized by precipitation using $50 \mu \mathrm{L}$ absolute ethanol kept at $4{ }^{\circ} \mathrm{C}$, followed by stirring and then kept for $30 \mathrm{~min}$ in a freezer at $-20^{\circ} \mathrm{C}$. The supernatant was centrifuged at $4000 \mathrm{~g}\left(10 \mathrm{~min}, 25^{\circ} \mathrm{C}\right)$. Levels of $6-$ keto-PGF $1 \alpha$ were measured using a commercially available kit (Cayman, code 515211). Results are reported as $\mathrm{pg} / \mathrm{mg}$ protein. Protein concentrations were determined with a protein assay reagent (Bio-Rad Laboratories).

\section{Drugs}

ODQ, 7-nitroindazole, SC560, and glibenclamide were prepared as stock solutions in dimethyl sulfoxide (DMSO), whereas the other drugs were dissolved in distilled water. The bath concentration of DMSO did not exceed $0.5 \%$, which was shown to have no effects per se on basal tonus of the preparations or on agonist-mediated relaxation.

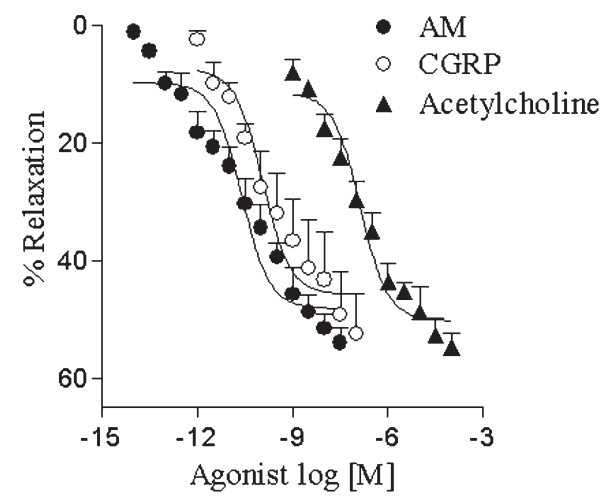

Figure 3. Concentration-response curves for AM, CGRP, and acetylcholine obtained in isolated rat cavernosal smooth muscle strips. The curves were obtained in CSM pre-contracted with phenylephrine $(10 \mu \mathrm{M})$. Data are reported as means \pm SE of 5 to 6 independent preparations. AM: adrenomedullin; CGRP: calcitonin gene-related peptide. 

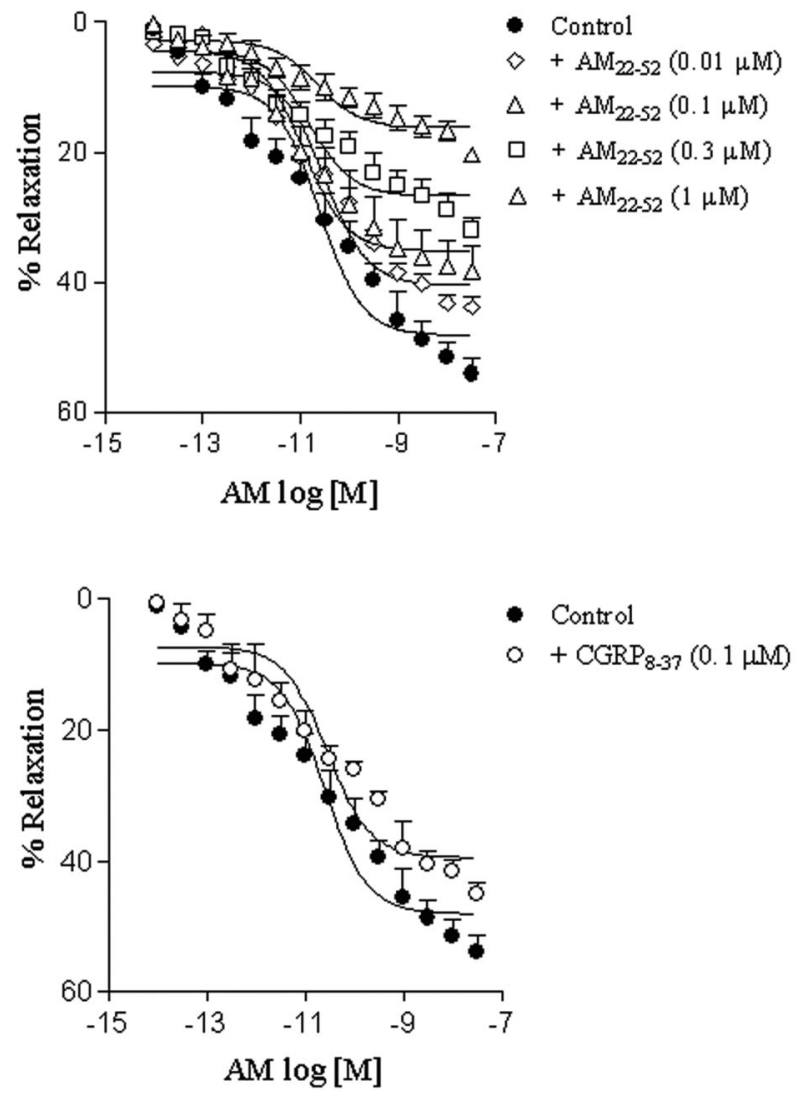

Figure 4. Concentration-response curves for AM obtained in rat cavernosal smooth muscle strips in the absence or presence of 0.01-1 $\mu \mathrm{M} \mathrm{AM}_{22-52}$ and 0.1 $\mu \mathrm{M} \mathrm{CGRP}_{8-37}$. Data are reported as means \pm SE of 5 to 6 independent preparations. AM: adrenomedullin; CGRP: calcitonin gene-related peptide.

\section{Statistical analysis}

Data are reported as means \pm SE. Statistically significant differences were determined by the Student $t$-test or analysis of variance (ANOVA) followed by the Bonferroni multiple comparison test. $\mathrm{P}<0.05$ was considered to be statistically significant.

\section{Results}

\section{Protein and mRNA expression of AM system components in rat CSM}

Figure $1 \mathrm{~A}$ shows representative immunoblots for $\mathrm{AM}$, CRLR, and RAMP1, -2 , and -3 protein expression in rat CSM. The results obtained by qRT-PCR showed that rat CSM expressed mRNA of pre-pro-AM, CRLR, and RAMP1, -2, and -3 (Figure 1B).

Expression and localization of $A M$ and CRLR in rat CSM. Immunohistochemical studies revealed staining for $A M$ and CRLR in rat cavernous tissue. Nuclear staining for both $A M$ and CRLR were detected diffusely in all constituents of the cavernous tissue including connective
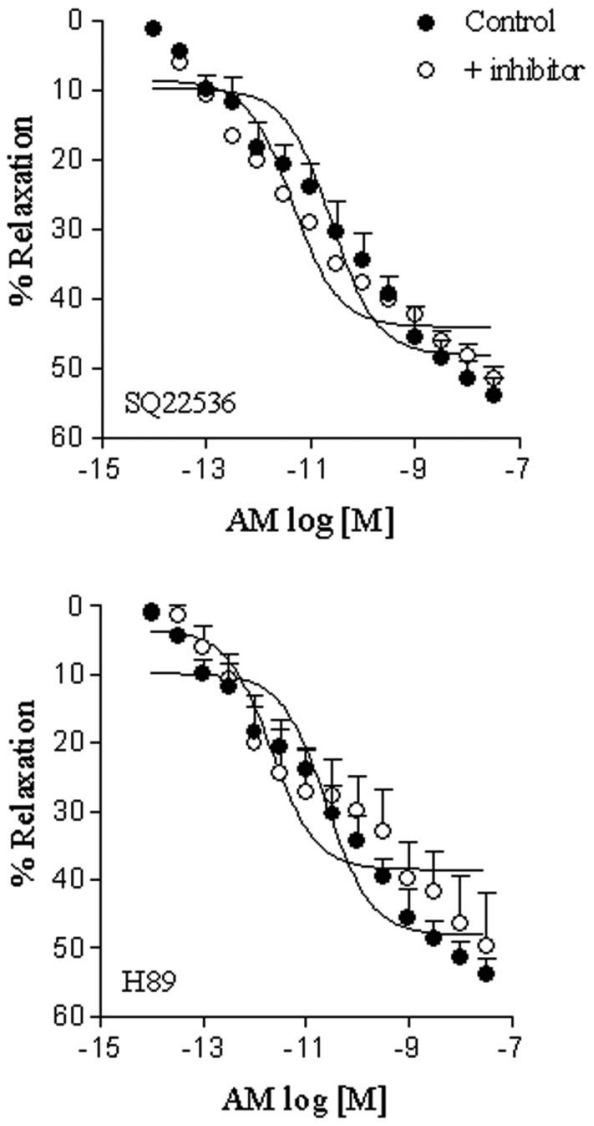

Figure 5. Relaxation responses induced by adrenomedullin (AM) on rat cavernosal smooth muscle strips pre-contracted with phenylephrine. The concentration-response curves were obtained in the absence (control) or after incubation for $30 \mathrm{~min}$ with $100 \mu \mathrm{M}$ SQ22536 (top) or $1 \mu \mathrm{M} \mathrm{H89} \mathrm{(bottom).} \mathrm{Data} \mathrm{are}$ reported as means \pm SE of 5 independent preparations.

tissue, in the endothelium lining vascular spaces, and in smooth muscle (Figure 2).

Mechanisms underlying the relaxant effect induced by $A M$ in isolated CSM strips. AM relaxed rat CSM strips in a concentration-dependent manner ( $E_{\max }: 53.9 \pm 2.5 \%$; $\mathrm{pD}_{2}$ : $\left.10.6 \pm 0.2, \mathrm{n}=6\right)$. Similarly, CGRP $\left(\mathrm{E}_{\max }\right.$ : $\left.52.5 \pm 6.9 \% ; \mathrm{pD}_{2}: 10.0 \pm 0.2, \mathrm{n}=6\right)$ and acetylcholine $\left(E_{\max }: 54.7 \pm 2.3 \% ; \mathrm{pD}_{2}: 6.8 \pm 0.2, \mathrm{n}=5\right.$ ) relaxed $\mathrm{CSM}$ strips (Figure 3 ). The maximal relaxation induced by the agonists was of similar magnitude. However, AM and CGRP were more potent than acetylcholine at inducing CSM relaxation $(\mathrm{P}<0.05$, ANOVA).

In order to verify the mechanisms underlying AMinduced relaxation, CSM strips were exposed to a variety of drugs. $\mathrm{AM}_{22-52}$, a selective antagonist for $\mathrm{AM}$ receptors, reduced the maximal relaxation induced by $A M$ in isolated rat CSM. The relaxation induced by $A M\left(E_{\text {max }}: 53.9 \pm 2.5 \%\right.$; $\left.\mathrm{pD}_{2}: 10.9 \pm 0.3, \mathrm{n}=6\right)$ was significantly reduced $(\mathrm{P}<0.05$, ANOVA) in the presence of $\mathrm{AM}_{22-52}$ at concentrations of 

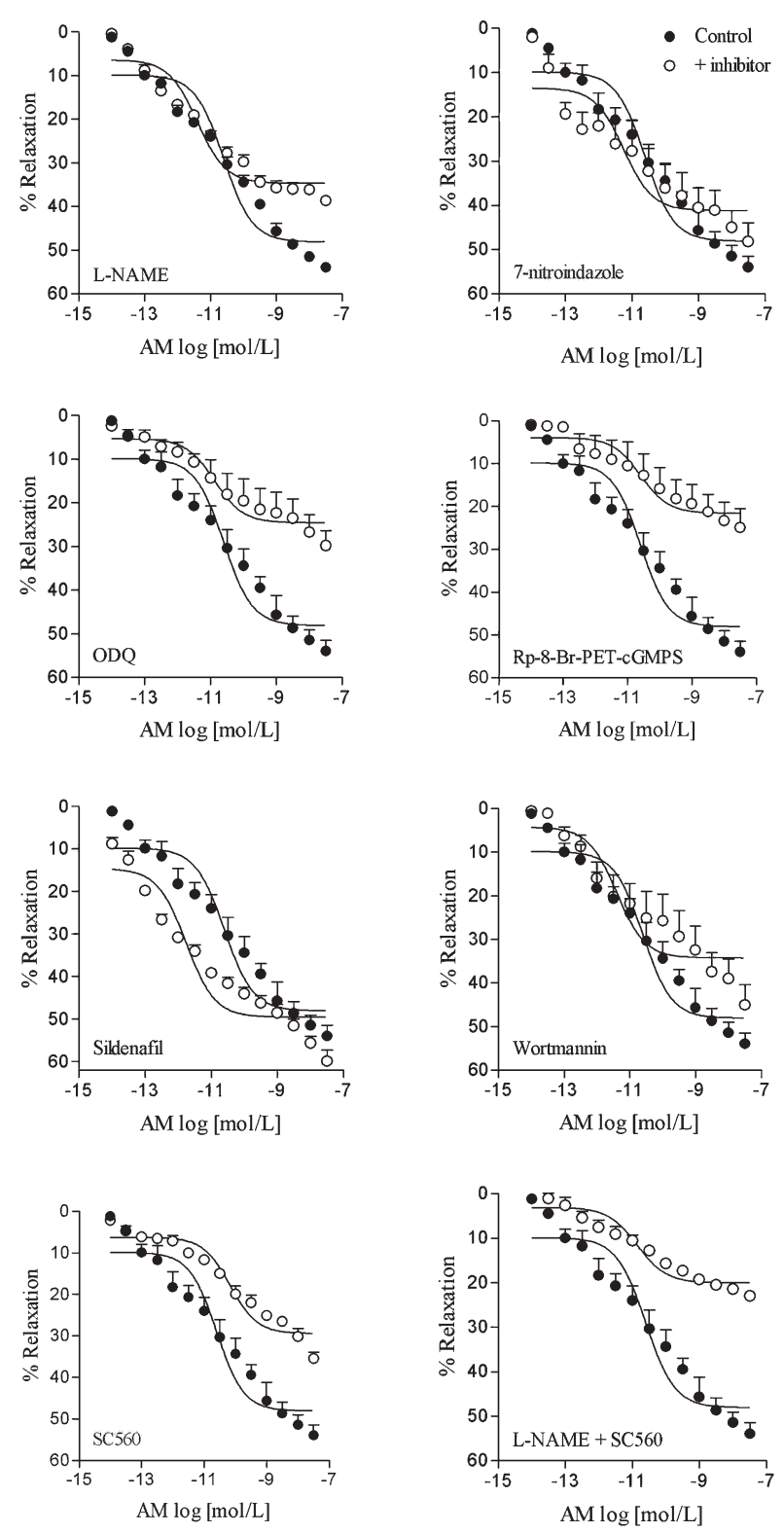

Figure 6. Relaxation responses induced by adrenomedullin (AM) on rat cavernosal smooth muscle strips pre-contracted with phenylephrine. The concentration-response curves were obtained in the absence (control) or after incubation for $30 \mathrm{~min}$ with the following drugs: $100 \mu \mathrm{M}$ L-NAME, $100 \mu \mathrm{M}$ 7-nitroindazole, $1 \mu \mathrm{M}$ ODQ, $3 \mu \mathrm{M}$ Rp-8-Br-PET-cGMPS, $10 \mu \mathrm{M}$ sildenafil, $1 \mu \mathrm{M}$ wortmannin, $10 \mu \mathrm{M} \mathrm{SC} 560$, or the combination of L-NAME and SC560. Data are reported as means \pm SE of 5 to 6 independent preparations.

$0.1 \mu \mathrm{M}\left(\mathrm{E}_{\max }: 38.3 \pm 3.9 \% ; \mathrm{pD}_{2}: 10.8 \pm 0.4, \mathrm{n}=6\right), 0.3 \mu \mathrm{M}$ $\left(E_{\max }: 31.9 \pm 1.9 \% ; \mathrm{pD}_{2}: 10.8 \pm 0.2, \mathrm{n}=6\right)$ and $1 \mu \mathrm{M}\left(\mathrm{E}_{\max }\right.$ : $20.4 \pm 0.9 \% ; \mathrm{pD}_{2}: 10.6 \pm 0.2, \mathrm{n}=6$ ) (Figure 4). At the concentration of $0.01 \mu \mathrm{M}, \mathrm{AM}_{22-52}$ did not affect $\mathrm{AM}$-induced relaxation ( $\left.E_{\max }: 43.8 \pm 1.5 \% ; \mathrm{pD}_{2}: 10.5 \pm 0.1, \mathrm{n}=6\right)$.
Similarly, $\mathrm{CGRP}_{8-37}\left(\mathrm{E}_{\max }: 44.1 \pm 1.8 \% ; \mathrm{pD}_{2}: 10.6 \pm 0.3\right.$, $\mathrm{n}=6$ ) did not alter the relaxation induced by AM (Figure 4). Neither H89 ( $\left.E_{\text {max }}: 49.7 \pm 7.7 \% ; D_{2}: 11.1 \pm 0.4, n=5\right)$ nor SQ22536 ( $E_{\text {max }}: 51.6 \pm 1.8 \% ; D_{2}: 11.4 \pm 0.2, n=5$ ) altered AM-induced relaxation (Figure 5). L-NAME, ODQ, Rp-8-BrPET-cGMPS, and SC560 reduced AM-induced relaxation to a similar extent (Figure 6, Table 1). The combination of L-NAME and SC560 showed further suppression of AM relaxation than that observed with either L-NAME or SC560 alone. However, even when combined, these compounds were not able to abolish AM-induced relaxation. Sildenafil induced a leftward displacement in the concentrationresponse curve for AM. Conversely, 7-nitroindazole and wortmannin did not alter the relaxation induced by AM (Figure 6, Table 1). 4-Aminopyridine, but not apamin or glibenclamide, reduced the relaxation induced by $\mathrm{AM}$ in rat CSM (Figure 7, Table 1).

\section{Nitrate and 6-keto-PGF ${ }_{1 \alpha}$ measurements}

AM significantly increased 6-keto-PGF ${ }_{1 \alpha}$ (a stable product of $\mathrm{PGI}_{2}$ ) in rat CSM compared with tissues that were not stimulated with the peptide (Figure 8A). AM significantly increased nitrate generation in rat CSM compared with tissues that were not stimulated with the peptide (Figure 8B). AM-induced nitrate generation was significantly inhibited by L-NAME, which had no effect per se on basal nitrate levels.

\section{Discussion}

In the present study, protein and mRNA expression of AM, CRLR, and RAMP1, -2 , and -3 were detected in rat CSM. Immunohistochemical assays showed that AM and CRLR are expressed in the cavernous tissue. AM acts as a circulating hormone and locally in an autocrine/ paracrine fashion. Because $A M$ is expressed in rat CSM, it may play a role in the autocrine/paracrine regulation of penile erection due to its vasodilator action. AM is considered an important regulatory peptide that helps to regulate cardiovascular homeostasis. AM levels in cardiovascular tissues are elevated to compensate for changes induced by cardiovascular diseases such as atherosclerosis and hypertension (24). Thus, increased AM expression in CSM could exert a protective action against ED. In fact, it has been suggested that combination therapy using $\mathrm{PGE}_{1}$ and proerection agents such as AM may be beneficial in the treatment of ED (25).

A pharmacological characterization of the mechanisms mediating the relaxant effect of AM in rat CSM was attempted with functional assays, using standard muscle bath procedures. AM induced CSM relaxation in a concentration-dependent manner. AM was similar in potency to CGRP, and both were more potent than acetylcholine, which is in accordance with previous findings in rat aorta (26), rat mesenteric arterial bed (27), and cat CSM (6). Relaxation induced by AM has 
Table 1. Effect of L-NAME, 7-nitroindazole, ODQ (1H-(1,2,4)oxadiazolo[4,3-a]quinoxalin-1-one), wortmannin, Rp-8-Br-PET-cGMPS, sildenafil, and SC560 on the $\mathrm{E}_{\max }$ and $\mathrm{pD}_{2}$ values for adrenomedullin in the isolated rat cavernosal smooth muscle.

\begin{tabular}{lcc}
\hline Inhibitor & $\mathrm{E}_{\max }(\%$ relaxation $)$ & $\mathrm{pD}_{2}$ \\
\hline Absent & $53.9 \pm 2.5$ & $10.9 \pm 0.3(6)$ \\
L-NAME $(100 \mu \mathrm{M})$ & $38.6 \pm 2.8^{*}$ & $11.6 \pm 0.2(6)$ \\
7-nitroindazole $(100 \mu \mathrm{M})$ & $48.2 \pm 4.1$ & $11.4 \pm 0.4(6)$ \\
ODQ $(1 \mu \mathrm{M})$ & $29.8 \pm 3.4^{*}$ & $10.5 \pm 0.4(5)$ \\
Rp-8-Br-PET-cGMPS $(3 \mu \mathrm{M})$ & $24.9 \pm 4.3^{*}$ & $10.6 \pm 0.5(5)$ \\
Sildenafil $(10 \mu \mathrm{M})$ & $59.9 \pm 2.6$ & $12.1 \pm 0.2^{*}(6)$ \\
Wortmannin $(1 \mu \mathrm{M})$ & $45.1 \pm 4.7$ & $10.5 \pm 0.3(5)$ \\
SC560 $(10 \mu \mathrm{M})$ & $35.5 \pm 1.5^{*}$ & $10.2 \pm 0.1(5)$ \\
L-NAME $+\mathrm{SC} 560$ & $23.0 \pm 0.8^{\star \#}$ & $11.1 \pm 0.3(5)$ \\
Glibenclamide $(3 \mu \mathrm{M})$ & $48.6 \pm 1.3$ & $11.2 \pm 0.1(6)$ \\
Apamin $(1 \mu \mathrm{M})$ & $47.3 \pm 1.2$ & $11.3 \pm 0.2(5)$ \\
4-aminopiridine $(1 \mathrm{mM})$ & $39.7 \pm 0.7^{*}$ & $10.6 \pm 0.2(6)$ \\
\hline
\end{tabular}

Data are reported as means \pm SE. Number between parentheses indicates the number of animals. ${ }^{*} \mathrm{P}<0.05$, compared to control; ${ }^{\#} \mathrm{P}<0.05$, compared to L-NAME and SC560 (ANOVA followed by the Bonferroni multiple comparison test).

been previously described in isolated rabbit CSM in a concentration range different from that employed in the present study (11). A possible explanation for such discrepancy is that the mechanism by which AM induces vasorelaxation or erection varies with species, vascular bed studied, and experimental procedure employed (5$7,11,28)$.

The AM receptor is composed of the CRLR and specific RAMP $(9,10)$. RAMPs are a class of type I transmembrane proteins that interact with and modulate the activities of $\mathrm{G}$ protein-coupled receptors. Cell surface RAMP2-CRLR and RAMP3-CRLR complexes are AM receptors, while the RAMP1-CRLR complex forms the CGRP receptor $(9,10)$. RAMP interaction with its associated receptor can lead to three potential consequences: trafficking of receptor protein from an intracellular compartment to the cell surface, alteration in the terminal glycosylation of the receptor, and alteration of receptor phenotype, presumably through a direct or indirect effect on the ligand-binding site (29). Although the antagonist $A M_{22-52}$ has been shown to selectively inhibit $A M$ receptors, $\mathrm{CGRP}_{8-37}$ is a CGRP receptor antagonist that has been shown to be able to block some, but not all, of the actions of AM in the vasculature (30). This observation indicates that the vasorelaxation induced by AM may occur due to its interaction with both AM or CGRP receptors. The present findings show that AM-induced CSM relaxation was attenuated by $A_{22}-52$, but not $\mathrm{CGRP}_{8 \text {-37. }}$. Our study provides the first functional evidence that relaxation induced by AM in rat CSM is solely mediated by AM receptors.

Activation of adenylate cyclase with consequent increase in CAMP and CAMP-dependent protein kinase activation has been implicated in the vascular relaxation induced by AM (31,32). In our study, neither SQ22536 nor H89 altered AM-induced relaxation, which is not consistent with the participation of adenylate cyclase and protein kinase in this response.
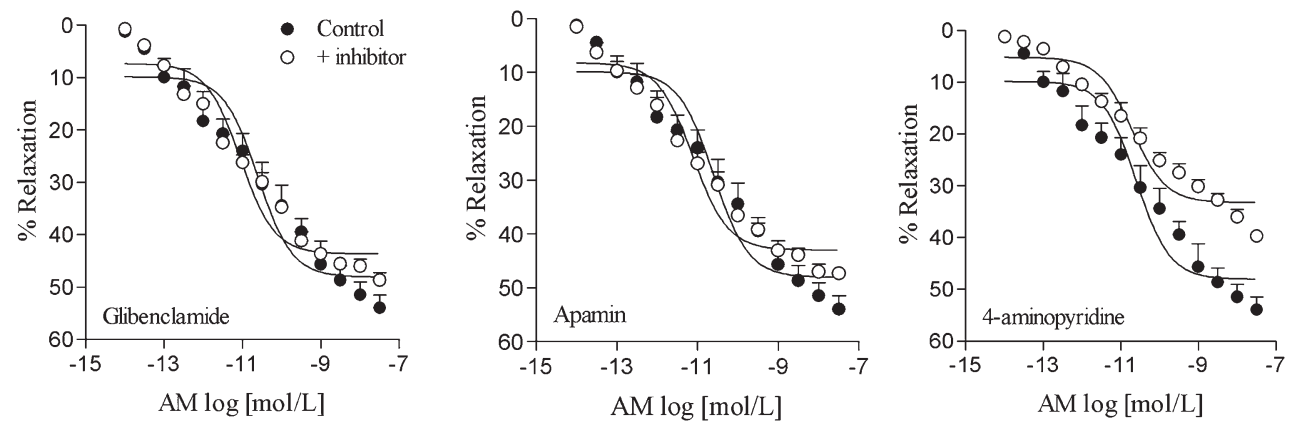

Figure 7. Relaxation responses induced by adrenomedullin (AM) on rat cavernosal smooth muscle strips pre-contracted with phenylephrine. The concentration-response curves were obtained in the absence (control) or after incubation for 30 min with $3 \mu \mathrm{M}$ glibenclamide, $1 \mu \mathrm{M}$ apamin, or $1 \mathrm{mM}$ 4-aminopyridine. Data are reported as means \pm SE of 5 to 6 independent preparations. 

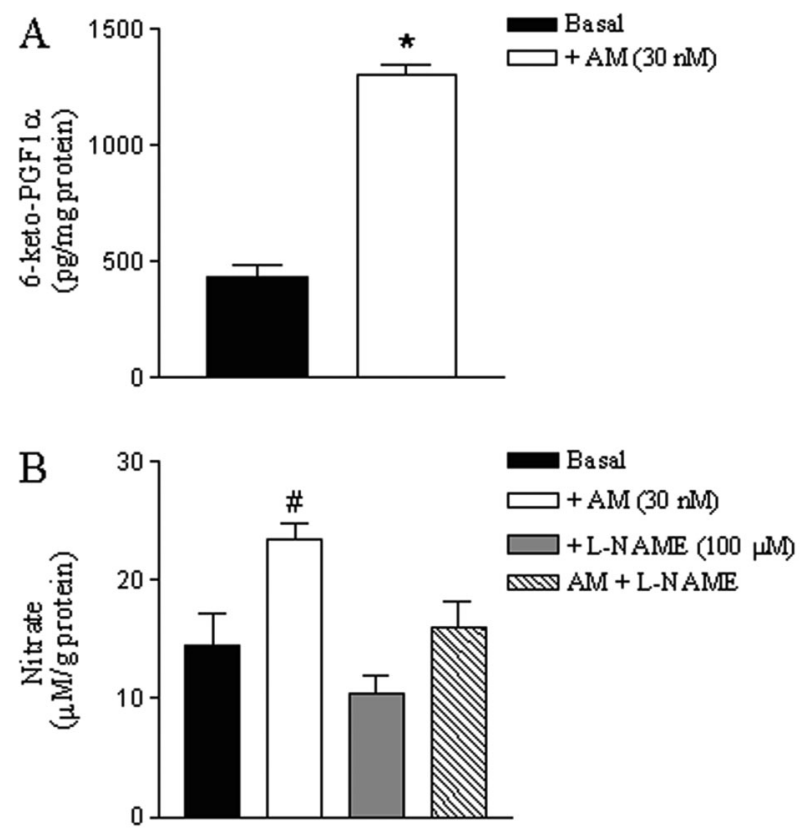

Figure 8. 6-keto-PGF $1 \alpha$ and nitrate levels in rat cavernosal smooth muscle strips stimulated with adrenomedullin (AM). Data are reported as means \pm SE of 5 to 6 independent preparations. ${ }^{*} \mathrm{P}<0.05$, compared to basal (Student $t$-test); ${ }^{\#} \mathrm{P}<0.05$, compared to basal, L-NAME, and AM + L-NAME (ANOVA followed by the Bonferroni multiple comparison test).

In some vascular tissues, AM induces relaxation via production of $\mathrm{NO}$, with consequent increases in cGMP levels $(33,34)$. $\mathrm{NO}$ is formed from L-arginine by the catalytic action of the enzyme NOS. The latter has three isoforms: nNOS (or NOS type I), inducible NOS (or NOS type II), and endothelial NOS (eNOS or NOS type III). nNOS and eNOS are the main isoforms involved in penile erection and are present in the nerves and endothelium of the penis, respectively (35). Our data show that L-NAME partially, but significantly, reduced AM-mediated relaxation. In addition, AM increased nitrate levels in rat CSM, and this response was inhibited by L-NAME, further implicating NOS in this process. Taken together, these results show that activation of NOS with consequent NO generation play a role in AM-mediated relaxation. 7Nitroindazole, a selective nNOS inhibitor, had no effect on AM-induced relaxation, suggesting that this NOS isoform could not account for the AM-mediated relaxation in rat CSM. The selective inhibitor of guanylyl cyclase enzyme, $O D Q$, reduced the relaxant action of $A M$, confirming the involvement of the NO-cGMP pathway in this response as previously observed in cat and rat CSM (5-7). cGMPstimulated protein kinase (PKG) acts downstream to reduce $\mathrm{Ca}^{2+}$ concentration and/or the sensitivity of the contractile proteins to $\mathrm{Ca}^{2+}$, thus leading to smooth muscle relaxation. Our findings show that PKG activation plays a role in AM-induced relaxation because $\mathrm{Rp}-8-\mathrm{Br}$ PET-cGMPS reduced this response. Phosphodiesterase type 5 (PDE5) is widely expressed in CSM, where it catalyzes cGMP hydrolysis (36). Sildenafil, a PDE5 inhibitor, induced a leftward displacement of the concentration-response curves for AM, further suggesting that PDE5 negatively modulates the relaxation induced by AM.

AM has also been shown to elicit phosphatidylinositol 3-kinase (PI3K) activation and Akt phosphorylation, resulting in the stimulation of eNOS (37). Our findings with wortmannin discard the participation of the PI3K/Akt pathway on AM-induced relaxation. It is important to note that blockade of the NO-cGMP pathway only partially attenuated the relaxant response induced by $A M$, indicating that mediators unrelated to the production of $\mathrm{NO}$ also participate in this response. In fact, we observed that the relaxation evoked by AM was partially blunted by SC560, an inhibitor of cyclooxygenase-1, suggesting the involvement of vasodilator prostanoids in the relaxing effect of AM. Additionally, AM increased 6-keto-PGF $1 \alpha$, a stable product of $\mathrm{PGI}_{2}$. These results agree with a previous finding showing the participation of prostanoids in AMinduced relaxation in porcine ciliary arteries (38). When L-NAME and SC560 were simultaneously added to the organ bath, an additional inhibitory effect on AM-induced relaxation was observed, indicating that both $\mathrm{NO}$ and vasodilator prostanoids participate in this response.

Activation of $\mathrm{K}^{+}$channels is an important mechanism in vascular smooth muscle hyperpolarization and relaxation, and cGMP can modulate the activity of $\mathrm{K}^{+}$channels to elicit vasodilatation. A role for $\mathrm{K}^{+}$channels in $\mathrm{AM}$ mediated relaxation has already been described for vasculature $(27,38)$. We found that 4 -aminopyridine, but not glibenclamide or apamin, reduced AM-induced relaxation, indicating that the activation of voltage-sensitive $\mathrm{K}^{+}$ channels plays a role in such responses.

The major new finding of the present study is that AM receptors mediate CSM relaxation via the NO-CGMP pathway, vasodilator prostanoids (probably $\mathrm{PGI}_{2}$ ), and the opening of $\mathrm{K}^{+}$channels. Studies of the expression and function of AM receptors in CSM may provide valuable information on the contribution of AM to CSM tone, since this tissue is a useful model for the study of penile erectile responses and ED.

\section{Acknowledgments}

Research supported by FAPESP (\#2006/60076-7 and \#2011/12911-2). L.N. Leite was supported by a master fellowship from CAPES. 


\section{References}

1. Andersson KE, Wagner G. Physiology of penile erection. Physiol Rev 1995; 75: 191-236.

2. Saenz de Tejada I, Goldstein I, Krane RJ. Local control of penile erection. Nerves, smooth muscle, and endothelium. Urol Clin North Am 1988; 15: 9-15.

3. Burnett AL, Lowenstein CJ, Bredt DS, Chang TS, Snyder SH. Nitric oxide: a physiologic mediator of penile erection. Science 1992; 257: 401-403, doi: 10.1126/science.1378650.

4. Lue TF. Erectile dysfunction. N Engl J Med 2000; 342: 1802-1813, doi: 10.1056/NEJM200006153422407.

5. Champion HC, Wang R, Shenassa BB, Murphy WA, Coy $\mathrm{DH}$, Hellstrom WJ, et al. Adrenomedullin induces penile erection in the cat. Eur J Pharmacol 1997; 319: 71-75, doi: 10.1016/S0014-2999(96)00924-7.

6. Champion HC, Wang R, Santiago JA, Murphy WA, Coy DH, Kadowitz PJ, et al. Comparison of responses to adrenomedullin and calcitonin gene-related peptide in the feline erection model. J Androl 1997; 18: 513-521.

7. Nishimatsu H, Hirata $Y$, Hayakawa H, Nagata D, Satonaka $\mathrm{H}$, Suzuki $\mathrm{E}$, et al. Effects of intracavernous administration of adrenomedullin on erectile function in rats. Peptides 2001; 22: 1913-1918, doi: 10.1016/S0196-9781(01)005216.

8. Kitamura K, Kangawa K, Kawamoto M, Ichiki Y, Nakamura $\mathrm{S}$, Matsuo $\mathrm{H}$, et al. Adrenomedullin: a novel hypotensive peptide isolated from human pheochromocytoma. Biochem Biophys Res Commun 1993; 192: 553-560, doi: 10.1006/ bbrc.1993.1451.

9. McLatchie LM, Fraser NJ, Main MJ, Wise A, Brown J, Thompson $\mathrm{N}$, et al. RAMPs regulate the transport and ligand specificity of the calcitonin-receptor-like receptor. Nature 1998; 393: 333-339, doi: 10.1038/30666.

10. Poyner DR, Sexton PM, Marshall I, Smith DM, Quirion R, Born W, et al. International Union of Pharmacology. XXXII. The mammalian calcitonin gene-related peptides, adrenomedullin, amylin, and calcitonin receptors. Pharmacol Rev 2002; 54: 233-246, doi: 10.1124/pr.54.2.233.

11. Gokce G, Bagcivan I, Kilicarslan H, Yildirim S, Gultekin YE, Sarioglu Y. Relaxation effects of adrenomedullin in isolated rabbit corpus cavernosum smooth muscle. BJU Int 2004; 93: 859-862, doi: 10.1111/j.1464-410X.2003.04728.x.

12. Marinoni E, di lorio R, Villaccio B, Vellucci O, Di Netta T, Sessa M, et al. Adrenomedullin in human male reproductive system. Eur J Obstet Gynecol Reprod Biol 2005; 122: 195198, doi: 10.1016/j.ejogrb.2005.03.021.

13. Hinson JP, Kapas S, Smith DM. Adrenomedullin, a multifunctional regulatory peptide. Endocr Rev 2000; 21: 138167.

14. Kloner RA. Sex and the patient with cardiovascular risk factors: focus on sildenafil. Am J Med 2000; 109 (Suppl 9A): 13S-21S, doi: 10.1016/S0002-9343(00)00656-2.

15. Carneiro FS, Carneiro ZN, Giachini FR, Lima VV, Nogueira $E$, Rainey WE, et al. Murine and rat cavernosal responses to endothelin-1 and urotensin-II Vasoactive Peptide Symposium. J Am Soc Hypertens 2008; 2: 439-447, doi: 10.1016/j.jash.2008.07.001.

16. Lizarte FS, Morgueti M, Tirapelli CR, Claudino MA, Evora PR, Novais PC, et al. Chronic alcoholism associated with diabetes impairs erectile function in rats. BJU Int 2010; 105 : 1592-1597, doi: 10.1111/j.1464-410X.2009.09084.x.

17. Lizarte FS, Claudino MA, Tirapelli CR, Morgueti M, Tirapelli DP, Batalhao ME, et al. Chronic ethanol consumption induces cavernosal smooth muscle dysfunction in rats. Urology 2009; 74: 1250-1256, doi: 10.1016/j.urology.2009. 04.043.

18. Lin RJ, Wu BN, Lo YC, Shen KP, Lin YT, Huang CH, et al. KMUP-1 relaxes rabbit corpus cavernosum smooth muscle in vitro and in vivo: involvement of cyclic GMP and $\left.\mathrm{K}^{+}\right)$ channels. $\mathrm{Br} J$ Pharmacol 2002; 135: 1159-1166, doi: 10.1038/sj.bjp.0704554.

19. Dalaklioglu S, Ozbey G. Role of different types of potassium channels in the relaxation of corpus cavernosum induced by resveratrol. Pharmacogn Mag 2014; 10: 47-52, doi: 10 4103/0973-1296.126658.

20. Williams BA, Liu C, Deyoung L, Brock GB, Sims SM. Regulation of intracellular $\mathrm{Ca}^{2+}$ release in corpus cavernosum smooth muscle: synergism between nitric oxide and cGMP. Am J Physiol Cell Physiol 2005; 288: C650-C658, doi: 10.1152/ajpcell.00475.2004.

21. Simplicio JA, Pernomian L, Simao MR, Carnio EC, Batalhao $\mathrm{ME}$, Ambrosio SR, et al. Mechanisms underlying the vascular and hypotensive actions of the labdane ent-3acetoxy-labda-8(17),13-dien-15-oic acid. Eur J Pharmacol 2014; 726C: 66-76, doi: 10.1016/j.ejphar.2014.01.018.

22. Yang L, Tang Q, Hu BR, Xiang JZ. [Relaxant effect of ethanol on isolated rabbit corpus cavernosum and its mechanism]. Zhonghua Nan Ke Xue 2007; 13: 910-914.

23. Yogi A, Callera GE, Hipolito UV, Silva CR, Touyz RM, Tirapelli CR. Ethanol-induced vasoconstriction is mediated via redox-sensitive cyclo-oxygenase-dependent mechanisms. Clin Sci 2010; 118: 657-668, doi: 10.1042/CS20090 352.

24. Yanagawa B, Nagaya N. Adrenomedullin: molecular mechanisms and its role in cardiac disease. Amino Acids 2007; 32: 157-164, doi: 10.1007/s00726-005-0279-5.

25. Lau DH, Kommu S, Mumtaz FH, Morgan RJ, Thompson CS, Mikhailidis DP. The management of phosphodiesterase-5 (PDE5) inhibitor failure. Curr Vasc Pharmacol 2006; 4: 89-93, doi: 10.2174/157016106776359871.

26. Hipolito UV, Rocha JT, Martins-Oliveira A, Tirapelli DP, Jacob-Ferreira A, Batalhao ME, et al. Chronic ethanol consumption reduces adrenomedullin-induced relaxation in the isolated rat aorta. Alcohol 2011; 45: 805-814, doi: 10.1016/j.alcohol.2011.06.005.

27. Rocha JT, Hipolito UV, Martins-Oliveira A, Tirapelli DP, Batalhao ME, Carnio EC, et al. Ethanol consumption alters the expression and reactivity of adrenomedullin in the rat mesenteric arterial bed. Alcohol Alcohol 2012; 47: 9-17, doi: 10.1093/alcalc/agr141.

28. Ishimitsu $\mathrm{T}$, Ono $\mathrm{H}$, Minami J, Matsuoka $\mathrm{H}$. Pathophysiologic and therapeutic implications of adrenomedullin in cardiovascular disorders. Pharmacol Ther 2006; 111: 909927, doi: 10.1016/j.pharmthera.2006.02.004.

29. Sexton PM, Albiston A, Morfis M, Tilakaratne N. Receptor activity modifying proteins. Cell Signal 2001; 13: 73-83, doi: 10.1016/S0898-6568(00)00143-1. 
30. Hay DL, Conner AC, Howitt SG, Smith DM, Poyner DR. The pharmacology of adrenomedullin receptors and their relationship to CGRP receptors. J Mol Neurosci 2004; 22: 105-113, doi: 10.1385/JMN:22:1-2:105.

31. Okamura T, Ayajiki K, Kangawa K, Toda N. Mechanism of adrenomedullin-induced relaxation in isolated canine retinal arteries. Invest Ophthalmol Vis Sci 1997; 38: 56-61.

32. Takata F, Dohgu S, Nishioku T, Takahashi H, Harada E, Makino I, et al. Adrenomedullin-induced relaxation of rat brain pericytes is related to the reduced phosphorylation of myosin light chain through the cAMP/PKA signaling pathway. Neurosci Lett 2009; 449: 71-75, doi: 10.1016/j.neulet.2008.10.082.

33. Hirata $Y$, Hayakawa $H$, Suzuki $Y$, Suzuki E, Ikenouchi $H$, Kohmoto $\mathrm{O}$, et al. Mechanisms of adrenomedullin-induced vasodilation in the rat kidney. Hypertension 1995; 25: $790-$ 795, doi: 10.1161/01.HYP.25.4.790.

34. Hayakawa $\mathrm{H}$, Hirata $\mathrm{Y}$, Kakoki M, Suzuki $\mathrm{Y}$, Nishimatsu $\mathrm{H}$, Nagata $D$, et al. Role of nitric oxide-cGMP pathway in adrenomedullin-induced vasodilation in the rat. Hypertension 1999; 33: 689-693, doi: 10.1161/01.HYP.33.2.689.

35. Prieto D. Physiological regulation of penile arteries and veins. Int J Impot Res 2008; 20: 17-29, doi: 10.1038/sj. ijir.3901581.

36. Rybalkin SD, Yan C, Bornfeldt KE, Beavo JA. Cyclic GMP phosphodiesterases and regulation of smooth muscle function. Circ Res 2003; 93: 280-291, doi: 10.1161/01. RES.0000087541.15600.2B.

37. Nishimatsu H, Suzuki E, Nagata D, Moriyama N, Satonaka $\mathrm{H}$, Walsh $\mathrm{K}$, et al. Adrenomedullin induces endotheliumdependent vasorelaxation via the phosphatidylinositol 3kinase/Akt-dependent pathway in rat aorta. Circ Res 2001; 89: 63-70, doi: 10.1161/hh1301.092498.

38. Dettmann ES, Vysniauskiene I, Wu R, Flammer J, Haefliger IO. Adrenomedullin-induced endothelium-dependent relaxation in porcine ciliary arteries. Invest Ophthalmol Vis Sci 2003; 44: 3961-3966, doi: 10.1167/iovs.02-1312. 